\title{
SUBSPECIES BOUNDARIES OF THE WILD POTATOES \\ SOLANUM BULBOCASTANUM AND S. CARDIOPHYLLUM BASED ON MORPHOLOGICAL AND NUCLEAR RFLP DATA
}

\author{
Aarón Rodríguez \\ Departamento de Botánica y Zoología \\ Centro Universitario de Ciencias Biológicas y Agropecuarias \\ Universidad de Guadalajara \\ Apartado postal 139 \\ 45101 Zapopan, Jalisco, México \\ Y \\ DAVID M. SPOONER \\ Vegetable Crops Research Unit \\ Agricultural Research Unit, U.S.D.A. \\ Department of Horticulture \\ University of Wisconsin \\ Madison, Wisconsin, 53706-1590, U.S.A.
}

\begin{abstract}
Morphological data and single- to low-copy nuclear DNA restriction enzyme site data were used to test subspecies circumscriptions of Solanum bulbocastanum and S. cardiophyllum. A prior chloroplast DNA analysis showed these species to be part of two main clades: 1 . $S$. bulbocastanum subsp. bulbocastanum, S. bulbocastanum subsp. dolichophyllum, S. bulbocastanum subsp. partitum, S. cardiophyllum subsp. cardiophyllum and S. cardiophyllum subsp. lanceolatum, and 2 . S. cardiophyllum subsp. ehrenbergii and other Mexican diploid species. The nuclear DNA and morphological data showed $S$. cardiophyllum subsp. ehrenbergii to be slightly distinguishable from the other subspecies of $S$. cardiophyllum, and do not support the distinction of subspecies within either species. These data add to a growing body of evidence that there are too many wild potato taxa recognized.
\end{abstract}

Key words: nuclear RFLP, Solanum bulbocastanum, Solanum cardiophyllum, Solanum section Petota, taxonomy.

\section{RESUMEN}

Se analizan los límites intra-específicos de Solanum bulbocastanum y S. cardiophyllum utilizando caracteres morfológicos y sitios de restricción en ADN nuclear. Un estudio anterior, con base en sitios de restricción en ADN del cloroplasto, mostró a estas dos especies como parte de dos clados. El primero agrupó a S. bulbocastanum subsp. bulbocastanum, S. bulbocastanum subsp. 
dolichophyllum, S. bulbocastanum subsp. partitum, S. cardiophyllum subsp. cardiophyllum y S. cardiophyllum subsp. lanceolatum. El segundo incluyó a $S$. cardiophyllum subsp. ehrenbergii y otras especies diploides mexicanas. De acuerdo con los datos morfológicos y moleculares, $S$. cardiophyllum subsp. ehrenbergii es ligeramente diferente de las otras subespecies de $S$. cardiophyllum. Por otro lado, el análisis no apoya la distinción de subespecies. Por último, la información aquí presentada se suma a la evidencia publicada en otros artículos en el sentido del reconocimiento de un número demasiado alto de especies silvestres de papa.

Palabras clave: RFLP nuclear, Solanum bulbocastanum, Solanum cardiophyllum, Solanum sección Petota, taxonomía.

\section{INTRODUCTION}

Solanum L. sect. Petota Dumort., the potato and its wild relatives, is distributed from the southwestern United States to south-central Chile, with a concentration of diversity in the Andes. Hawkes (1990) recognized 232 species, partitioned into 21 series. Spooner and Hijmans (2001) updated this to 199 species, considering taxonomic changes since 1990. Within sect. Petota, there are widely different philosophies and taxonomic practices regarding species circumscriptions, the rank of infraspecific taxa, the placement of species into series, and the extent and evolutionary significance of interspecific hybridization (Spooner and Sytsma, 1992; Spooner and van den Berg, 1992a,b).

This study examines subspecies differentiation of two Mexican species, $S$. bulbocastanum Dunal and S. cardiophyllum Lindl., with phenetic analysis of morphological and single to low-copy nuclear RFLP data (nDNA). A prior chloroplast DNA (cpDNA) cladistic analysis (Rodríguez and Spooner, 1997) showed these species to be part of two well-supported clades: clade 1: Solanum bulbocastanum [subsp. bulbocastanum, subsp. dolichophyllum (Bitter) Hawkes, subsp. partitum (Correll) Hawkes] and S. cardiophyllum [subsp. cardiophyllum and subsp. lanceolatum (P. Berthault) Bitter], and clade 2. S. cardiophyllum subsp. ehrenbergii Bitter and other Mexican diploid species.

Taxonomically, Solanum bulbocastanum and S. cardiophyllum have been treated in different ways (Fig. 1). Rydberg (1924) and Correll (1962) recognized S. cardiophyllum subsp. ehrenbergii as a distinct species, S. ehrenbergii (Bitter) Rydb. Preliminary observations of live plants grown from a germplasm bank, study of herbarium specimens, and field observations (Spooner et al., 1991; Rodríguez et al., 1995) suggested to us that these subspecies were morphologically poorly defined.

Solanum bulbocastanum grows from west central Mexico to northwestern Guatemala, in generally open situations of tropical deciduous forests. Solanum cardiophyllum grows from west central Mexico to southern Mexico, in open situations of tropical deciduous forests, mesquite-cactus grasslands, and as a weed in corn and bean fields (Correll, 1962; Hawkes, 1990; Luna et al., 1988; Rodríguez, 1991). They are sympatric throughout much of their range.

Solanum bulbocastanum and $S$. cardiophyllum typically are diploid $(2 n=2 x=24)$, with occasional triploid cytotypes (Hawkes, 1990). Luna et al. (1988) report diploid, triploid, and even tetraploid cytotypes for $S$. cardiophyllum subsp. ehrenbergii. Solanum bulbocastanum, S. cardiophyllum, and all other Mexican diploid species (except $S$. verrucosum Schltdl.) are in similar crossing groups in that each has endosperm balance 
numbers (EBN: strong crossing barriers involving ratios of maternal and paternal effective ploidy in the endosperm, and governing endosperm function) of 1 (Hanneman, 1994).

Solanum bulbocastanum is one of the most morphologically distinctive species in sect. Petota. It has simple leaves, where the majority of wild potatoes have pinnately dissected leaves. All authors have classified it in ser. Bulbocastana (Rydb.) Hawkes (e. g. Rydberg, 1924; Correll, 1962; Flores Crespo, 1966; Bukasov, 1978; Hawkes, 1990). However, the composition of this series was different among authors, some making it monotypic, others including S. clarum Correll and S. morelliforme Bitter \& Münch (Spooner and Sytsma, 1992).
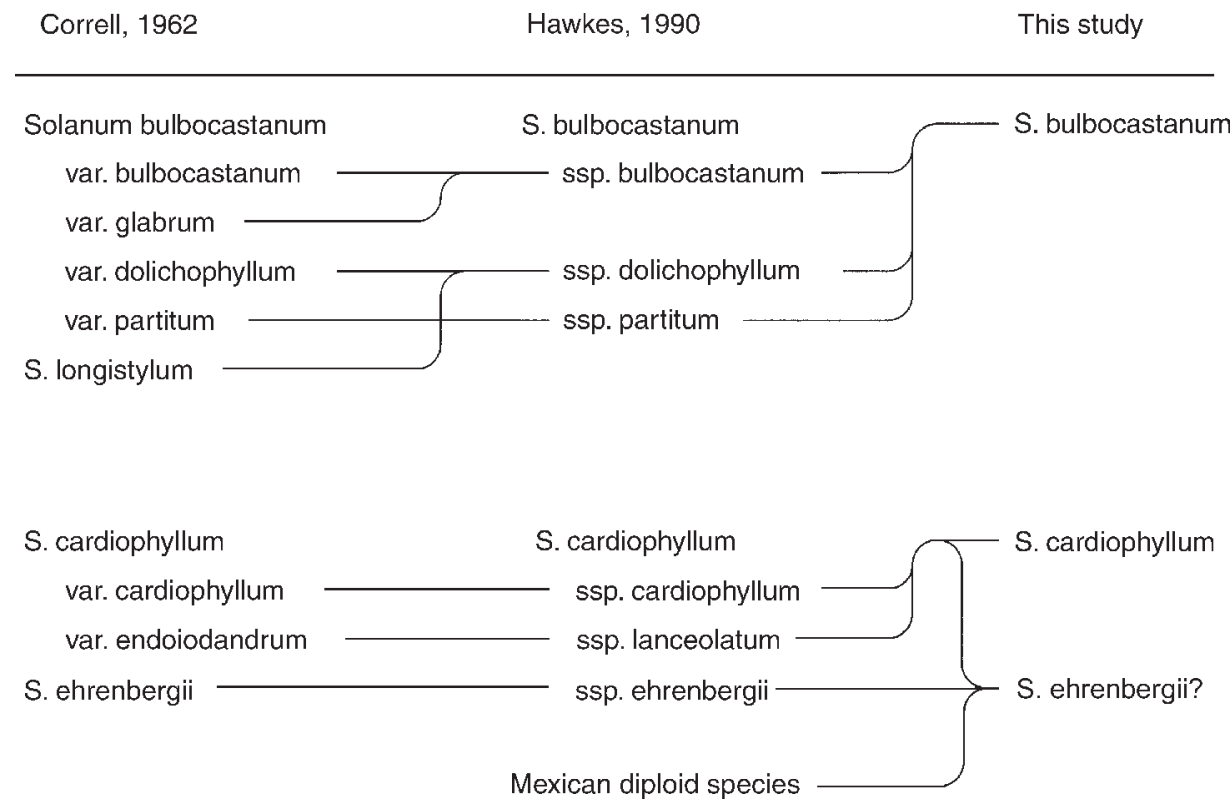

Fig. 1. A comparison of the classifications of infraspecific taxa of Solanum bulbocastanum and $S$. cardiophyllum of Correll (1962), Hawkes (1990), and this study.

Solanum cardiophyllum, on the other hand, has pinnately dissected leaves, but its combination of white to cream colored stellate corollas, usually shiny leaves, and cordate leaflets makes it distinctive and unlikely to be confused with any other wild potato except S. brachistotrichum (Bitter) Rydb. or S. stenophyllidium Bitter. It has been classified by various authors (e. g. Rydberg, 1924; Correll, 1962; Flores-Crespo, 1966; Bukasov, 1978; Hawkes, 1990) in ser. Cardiophylla Correll or ser. Pinnatisecta (Rydberg) Hawkes. Like ser. Bulbocastana, the placement of putative related species in ser. Cardiophylla and ser. Pinnatisecta has varied greatly (Spooner and Sytsma, 1992). 
A chloroplast DNA (cpDNA) study of 48 accessions of 26 Mexican and Central American species of sect. Petota, including two accessions each of $S$. bulbocastanum and S. cardiophyllum (Spooner and Sytsma, 1992), showed an unexpected result. These two species formed a distinct clade, well separated from all other Mexican diploid species with which they were thought to be closely related. Neither morphological, crossing, nor immunological data provided a clue to this cladistic relationship. Solanum bulbocastanum and $S$. cardiophyllum are very different morphologically and have always been placed in different series. Both can be hybridized artificially to form $F_{1}$ individuals with high pollen stainability, and fertile $F_{2}$ plants can be obtained from these (Magoon et al., 1958; Graham and Dionne, 1961). Not all attempts at this hybrid combination were successful (Swaminathan, 1955; Hawkes, 1958). However, equally fertile artificial hybrids also have been reported between $S$. bulbocastanum and $S$. cardiophyllum with other Mexican diploid species that previously were thought to be related (i. e., $S$. jamesii Torrey, S. pinnatisectum Dunal, S. trifidum Correll; Magoon et al., 1958; Graham et al., 1959; Graham and Dionne, 1961). Immunological studies (Gell et al., 1960) suggested that $S$. bulbocastanum, $S$. cardiophyllum, and other species in the Mexican diploid clade were equally related.

Restriction enzyme site polymorphisms from single- to low-copy nuclear DNA have been used to detect relationships within section Petota (Debener et al., 1990), and to investigate species and subspecies circumscriptions (Hosaka and Spooner, 1992; Giannattasio and Spooner, 1994b; Miller and Spooner, 1999). In addition, morphological studies are useful to test prior classifications (Fig. 1, Tables 1, 2), to check identities of germplasm and field collections, and to examine the relationship between morphological and molecular data. No explicit morphological or molecular study has ever been conducted to test subspecies circumscriptions of $S$. bulbocastanum and $S$. cardiophyllum.

This study is a counterpart to the cpDNA study of Rodríguez and Spooner (1997), using the same accessions as that study. The objective is to examine the support for subspecies of $S$. bulbocastanum and $S$. cardiophyllum using nDNA and morphology. The results are needed to determine the validity of these taxa for a taxonomic monograph of the wild potatoes of the USA, Mexico, and Central America, currently in progress.

Table 1. Morphological characters used by Hawkes (1990) to distinguish the subspecies of Solanum bulbocastanum.

\begin{tabular}{|l|l|l|l|}
\hline Character & \multicolumn{3}{|c|}{ Character states } \\
\cline { 2 - 4 } & subsp. bulbocastanum & subsp. dolichophyllum & \multicolumn{1}{|c|}{ subsp. partitum } \\
\hline Leaf shape & $\begin{array}{l}\text { Ovate to ovate-lanceo- } \\
\text { late; less than 2.5 times } \\
\text { as long as wide }\end{array}$ & $\begin{array}{l}\text { Linear-lanceolate; more } \\
\text { than 2.5 times as long } \\
\text { as wide }\end{array}$ & $\begin{array}{l}\text { Ovate to ovate-lanceo- } \\
\text { late; less than 2.5 times } \\
\text { as long as wide }\end{array}$ \\
Pedicel pubescence & $\begin{array}{l}\text { Pubescent both below } \\
\text { and above the articula- } \\
\text { tion }\end{array}$ & $\begin{array}{l}\text { Pubescent both below } \\
\text { and above the articula- } \\
\text { tion }\end{array}$ & $\begin{array}{l}\text { Pubescent below and } \\
\text { glabrous above the ar- } \\
\text { ticulation } \\
\text { Calyx pubescence } \\
\text { Corolla shape }\end{array}$ \\
$\begin{array}{l}\text { Pubescent } \\
\text { Lobed near the middle }\end{array}$ & $\begin{array}{l}\text { Glabrous } \\
\text { Lobed near the middle }\end{array}$ & \begin{tabular}{l} 
Lobed near the base \\
\hline
\end{tabular}
\end{tabular}


Rodríguez y Spooner: Subspecies the Solanum bulbocastanum and S. cardiophyllum

Table 2. Morphological characters used by Hawkes (1990) to distinguish the subspecies of Solanum cardiophyllum.

\begin{tabular}{|l|l|l|l|}
\hline \multirow{2}{*}{ Character } & \multicolumn{3}{|c|}{ Character states } \\
\cline { 2 - 4 } & \multicolumn{1}{|c|}{ subsp. cardiophyllum } & \multicolumn{1}{|c|}{ subsp. ehrenbergii } & \multicolumn{1}{c|}{ subsp. lanceolatum } \\
\hline Leaflet shape & Broadly ovate-cordate; & Oblong-lanceolate to lan & Lanceolate; more than \\
& less than 2.5 times as & ceolate; less than 2.5 & 2.5 times as long as \\
times as long as wide & wide \\
Sepal acumen length & long as wide & time & $0.5-1.0 \mathrm{~mm}$ \\
Anther length & $<0.5 \mathrm{~mm}$ & $0.5-1.5 \mathrm{~mm}$ & $5.0 \mathrm{~mm}$ \\
\hline
\end{tabular}

\section{MATERIALS AND METHODS}

Plants

Forty-seven accessions of $S$. bulbocastanum and $S$. cardiophyllum and one accession of $S$. pinnatisectum (representing a member of the Mexican diploid species clade) were analyzed for the nDNA study; with few exceptions, accessions were the same used in the cpDNA study of Rodríguez and Spooner (1997) (Table 3). The morphological study used plants of 65 accessions of $S$. bulbocastanum and $S$. cardiophyllum, including all those used for the cpDNA and nDNA studies (Table 3). Accessions were obtained from the United States potato germplasm bank of the National Research Support Program-6 (NRSP-6) at Sturgeon Bay, Wisconsin (Bamberg et al., 1996) and on an expedition to Mexico (Rodríguez et al., 1995), where these were the two target species.

Table 3. Accessions examined, arranged alphabetically and then geographically within taxa from the northwest to the southeast.

\begin{tabular}{|l|l|l|l|l|}
\hline Taxon $^{1}$ & Study & $\mathrm{Pl}^{3}$ & Collector & Locality \\
\hline 1. blb blb & M,C,N & 275187 & Hawkes 1584 & Mexico. Michoacán. \\
2. blb blb & M,C,N & 347757 & Tarn 153 & Mexico. Michoacán. \\
3. blb blb & M & 498225 & Ochoa 14163 & Mexico. Michoacán. \\
4. blb blb & M & 595475 & Rodríguez et al. 2555 & Mexico. Hidalgo. \\
5. blb blb & M & 275184 & Hawkes 1581 & Mexico. Distrito Federal. \\
6. blb blb & M,C,N & 275185 & Hawkes 1582 & Mexico. Distrito Federal. \\
7. blb blb & M,C,N & 275186 & Hawkes 1583 & Mexico. Distrito Federal. \\
8. blb blb & M,C,N & 275197 & Hawkes 1594 & Mexico. Distrito Federal. \\
9. blb blb & M,C,N & 275188 & Hawkes 1585 & Mexico. Ḿnico. \\
10. blb blb & M,C,N & 275189 & Hawkes 1586 & Mexico. México. Mexico. México. \\
11. blb blb & M,C,N & 275198 & Hawkes 1595 & Mexicos. México. \\
12. blb blb & M,C,N & 275199 & Hawkes 1596 & Mexico. Mas \\
\hline
\end{tabular}


Table 3. Continuation.

\begin{tabular}{|c|c|c|c|c|}
\hline Taxon $^{1}$ & Study ${ }^{2}$ & $\mathrm{Pl}^{3}$ & Collector & Locality ${ }^{4}$ \\
\hline 13. blb blb & $\mathrm{M}, \mathrm{C}, \mathrm{N}$ & 595471 & Rodríguez et al. 2546 & Mexico. México. \\
\hline 14. blb blb & $M, C$ & 275192 & Hawkes 1589 & Mexico. Tlaxcala. \\
\hline 15. blb blb & $M, C, N$ & 545711 & Tarn et al. 149 & Mexico. Guerrero. \\
\hline 16. blb blb & $M$ & 365379 & Tarn 224 & Mexico. Veracruz. \\
\hline 17. blb blb & $M, C, N$ & 275194 & Hawkes 1591 & Mexico. Oaxaca. \\
\hline 18. blb blb & $\mathrm{C}, \mathrm{N}$ & 275195 & Hawkes 1592 & Mexico. Oaxaca. \\
\hline 19. blb blb & $M, C, N$ & 275196 & Hawkes 1593 & Mexico. Oaxaca. \\
\hline 20. blb blb & $M, C, N$ & 283096 & Hawkes 1719 & Mexico. Oaxaca. \\
\hline 21. blb blb & $M, C, N$ & 498011 & Tarn et al. 173 & Mexico. Oaxaca. \\
\hline 22. blb blb & $M$ & 498223 & Ochoa 14142 & Mexico. Oaxaca. \\
\hline 23. blb blb & $M, C, N$ & 595464 & Rodríguez et al. 2509 & Mexico, Oaxaca. \\
\hline 24. blb blb & & & Rodríguez et al. 2510 & Mexico. Oaxaca. \\
\hline 25. blb blb & $M, C, N$ & & Rodríguez et al. 2518 & Mexico. Oaxaca. \\
\hline 26. blb blb & & & Rodríguez et al. 2522 & Mexico. Oaxaca. \\
\hline 27. blb blb & $M, C, N$ & & Rodríguez et al. 2523 & Mexico. Oaxaca. \\
\hline 28. blb blb & $\mathrm{M}$ & 347758 & Tarn $233 B$ & Mexico. \\
\hline 29. blb dph & C & & Rodríguez et al. 2580 & Mexico. Jalisco. \\
\hline 30. blb dph & $M, C$ & 590930 & Rodríguez et al. 2581 & Mexico. Jalisco. \\
\hline 31. blb dph & $M, C, N$ & 255516 & Graham 3008 & Mexico. Jalisco. \\
\hline 32. blb dph & $M$ & 255518 & Graham 313 & Mexico. Jalisco. \\
\hline 33. blb dph & $M$ & 545751 & Tarn et al. 237 & Mexico. Jalisco. \\
\hline 34. blb dph & $M, C, N$ & 498224 & Ochoa 14162 & Mexico. Michoacán. \\
\hline 35. blb dph & $\mathrm{M}, \mathrm{C}, \mathrm{N}$ & 545752 & Tarn et al. 244 & Mexico. México. \\
\hline 36. blb dph & $M, C, N$ & 595473 & Rodríguez et al. 2548 & Mexico. Morelos. \\
\hline 37. blb ptt & $M, C, N$ & 558379 & Spooner et al. 4224 & Mexico. Chiapas. \\
\hline 38. blb ptt & $M, C, N$ & 275200 & Hawkes 1796 & Guatemala. Quetzaltenango. \\
\hline 39. $\mathrm{cph} \mathrm{cph}$ & $M, N$ & 595482 & Rodríguez et al. 2570 & Mexico. Jalisco. \\
\hline 40. cph cph & $M, C, N$ & 283062 & Graham s. $n$. & Mexico. México. \\
\hline 41. cph cph & & 283063 & Graham s. $n$. & Mexico. México. \\
\hline 42. $\mathrm{cph} \mathrm{cph}$ & $\mathrm{M}, \mathrm{C}, \mathrm{N}$ & & Rodríguez et al. 2551 & Mexico. Morelos. \\
\hline 43. cph cph & $M, C, N$ & 347759 & Tarn $241 D$ & Mexico. Puebla. \\
\hline 44. cph cph & $M, C, N$ & 595465 & Rodríguez et al. 2529 & Mexico. Puebla. \\
\hline 45. cph cph & $M, C, N$ & 595468 & Rodríguez et al. 2541 & Mexico. Puebla. \\
\hline 46. cph ehr & $M$ & 186548 & Hawkes 1100 & Mexico. Zacatecas. \\
\hline 47. cph ehr & $M$ & 186549 & Hawkes 1102 & Mexico. Zacatecas. \\
\hline 48. cph ehr & $M$ & 545824 & Tarn et al. 228 & Mexico. Zacatecas. \\
\hline 49. cph ehr & $\mathrm{M}, \mathrm{N}$ & 595480 & Rodríguez et al. 2567 & Mexico. Zacatecas. \\
\hline 50. cph ehr & $M, C$ & 279272 & Hawkes 1458 & Mexico. Aguascalientes. \\
\hline 51. cph ehr & $M$ & 255520 & Graham 289 & Mexico. San Luis Potosí. \\
\hline 52. cph ehr & $M, N$ & 545753 & Tarn et al. 211 & Mexico. San Luis Potosí. \\
\hline 53. cph ehr & $\mathrm{M}, \mathrm{C}, \mathrm{N}$ & 595479 & Rodríguez et al. 2566 & Mexico. San Luis Potosí. \\
\hline 54. cph ehr & $M, C, N$ & 595486 & Rodríguez et al. 2579 & Mexico. Jalisco. \\
\hline 55. cph ehr & $M, C, N$ & 595488 & Rodríguez et al. 2584 & Mexico. Jalisco. \\
\hline 56. cph ehr & $\mathrm{C}, \mathrm{N}$ & & Rodríguez et al. 2586 & Mexico. Jalisco. \\
\hline 57. cph ehr & C,N & & Rodríguez 2588 & Mexico. Jalisco. \\
\hline 58. cph ehr & $M, C, N$ & 611097 & Rodríguez et al. 2564 & Mexico. Guanajuato. \\
\hline
\end{tabular}


Rodríguez y Spooner: Subspecies the Solanum bulbocastanum and S. cardiophyllum

Table 3. Continuation.

\begin{tabular}{|l|l|l|l|l|}
\hline Taxon $^{1}$ & Study $^{2}$ & $\mathrm{PI}^{3}$ & Collector & Locality4 \\
\hline 59. cph ehr & $\mathrm{M}, \mathrm{C}, \mathrm{N}$ & 184762 & Hawkes 1086 & Mexico. Querétaro. \\
60. cph ehr & $\mathrm{M}, \mathrm{C}, \mathrm{N}$ & 275216 & Hawkes 1421 & Mexico. Querétaro. \\
61. cph ehr & $\mathrm{M}$ & 275212 & Hawkes 1427 & Mexico. Querétaro. \\
62. cph ehr & $\mathrm{M}, \mathrm{C}$ & 275213 & Hawkes 1428 & Mexico. Querétaro. \\
63. cph ehr & $\mathrm{M}, \mathrm{C}, \mathrm{N}$ & 275214 & Hawkes 1429 & Mexico. Querétaro. \\
64. cph ehr & $\mathrm{M}$ & & Rodríguez et al. 2496 & Mexico. Querétaro. \\
65. cph ehr & $\mathrm{M}, \mathrm{C}, \mathrm{N}$ & & Rodríguez et al. 2497 & Mexico. Querétaro. \\
66. cph ehr & $\mathrm{M}$ & 595477 & Rodríguez et al. 2560 & Mexico. Querétaro. \\
67. cph ehr & $\mathrm{M}, \mathrm{C}, \mathrm{N}$ & 595466 & Rodríguez et al. 2533 & Mexico. Puebla. \\
68. cph Icl & $\mathrm{C}, \mathrm{N}$ & 595465 & Rodríguez et al. 2529L & Mexico. Puebla. \\
69. cph Icl & $\mathrm{M}, \mathrm{C}, \mathrm{N}$ & Still in & Rodríguez et al. 2534 & Mexico. Puebla. \\
70. cph Icl & $\mathrm{M}$ & quarant. & Rodríguez et al. 2544 & Mexico. Puebla. \\
71. pnt & $\mathrm{C}, \mathrm{N}$ & 275470 & Hawkes 1456 & Mexico. Jalisco. \\
\hline
\end{tabular}

${ }^{1}$ Numbers correspond to Figs. 3 and 4 of this paper and Fig. 5 of Rodríguez and Spooner (1997); taxon abbreviations follow Hawkes (1990): blb blb $=S$. bulbocastanum ssp. bulbocastanum, blb dph $=S$. bulbocastanum ssp. dolichophyllum, blb $\mathrm{ptt}=\mathrm{S}$. bulbocastanum ssp. partitum, $\mathrm{cph} \mathrm{cph}=S$. cardiophyllum ssp. cardiophyllum, $\mathrm{cph}$ ehr $=S$. cardiophyllum $\mathrm{ssp}$. ehrenbergii, $\mathrm{cph} \mathrm{Icl}=S$. cardiophyllum ssp. lanceolatum, pnt $=S$. pinnatisectum, pls $=S$. palustre. ${ }^{2} \mathrm{M}=$ Accesions examined in this morphological study; $\mathrm{C}=$ Accessions examined in the chloroplast DNA study of Rodríguez and Spooner (1997); $\mathrm{N}=$ Accessions examined in this nuclear DNA study. ${ }^{3}$ United States Department of Agriculture Plant Introduction Numbers; those collections without PI numbers did not make it through a successful germplasm increase. ${ }^{4}$ More complete locality data are available in Rodríguez and Spooner (1997).

Identities of the NRSP-6 accessions were provided by visiting taxonomists to NRSP-6 (Spooner and Bamberg, 1991), and are listed in Bamberg et al. (1996). Identities of the subspecies of $S$. bulbocastanum and $S$. cardiophyllum often were not clear during the 1993 expedition to Mexico (Rodríguez et al., 1995), and the plants were identified as expected based on type localities or our best interpretation of the keys in Hawkes (1990) (Tables 1, 2). The rare taxa $S$. bulbocastanum subsp. partitum (Correll) Hawkes and $S$. cardiophyllum subsp. lanceolatum were represented only by two accessions each for the molecular and morphological studies (Table 3). These accessions represent the greatest available geographic and subspecies diversity available from NRSP-6 and recent fieldwork. Voucher specimens for the entire study are deposited at the Mexican National Potato Program in Toluca, Mexico, the University of Guadalajara Herbarium (IBUG), and the United States Potato Introduction Herbarium (PTIS) (Bamberg and Spooner, 1994).

\section{Morphology}

Morphological analyses of $S$. bulbocastanum and S. cardiophyllum assessed 19 and 26 characters, respectively (Table 4). The NRSP-6 germplasm accessions were 
measured in an experimental field plot at Sturgeon Bay, Wisconsin, when the plants were in full bloom in September 1993. Other collections (Rodríguez et al., 1995) were measured in the field in Mexico in August and September 1993. Four plants were measured for all characters, and means were used as representative of each accession (the accession represents the Operational Taxonomic Unit, OTU). Measurements of leaves were made on the largest leaf per plant. Sepal acumen length was used by Hawkes (1990) to distinguish the subspecies of $S$. cardiophyllum (Table 2), and was measured for both this species and $S$. bulbocastanum in this study (Table 4). The base of the sepal acumen was measured from the most clearly evident beginning of maximum constriction. Corolla colors were measured with the aid of the R.H.S. Colour Charts (Anonymous, 1986), based on recommendations of Tucker et al. (1991). They were scored as 1-7: 1, violet blue (color 91D); 2, white (155A-D) with violet blue tips of the corolla lobes; 3, white (155A-D); 4, graywhite (156D); 5, yellow-white (158D); 6, yellow-white (158B); 7, yellow (2D).

Table 4. Morphological characters used in the phenetic analysis of Solanum bulbocastanum and $S$. cardiophyllum. Characters $6,7,8,9,10,11,12,13,14,15$ and 23 were not used in the $S$. bulbocastanum analysis; characters 3, 4, 5 and 22 were not used in the $S$. cardiophyllum analysis. All measurements are in milimeters.

\begin{tabular}{|c|c|}
\hline Leaf characters: & Floral characters: \\
\hline $\begin{array}{l}\text { 1. Leaf width. } \\
\text { 2. Ratio: leaf length/leaf width. } \\
\text { 3. Leaf length from axis of widest point to } \\
\text { apex. } \\
\text { 4. Ratio: leaf width/leaf length from axis of } \\
\text { widest point to apex. } \\
\text { 5. Petiole length. } \\
\text { 6. Terminal leaflet width. } \\
\text { 7. Terminal leaflet length from axis of widest } \\
\text { point to apex. } \\
\text { 8. Ratio: terminal leaflet length/terminal leaflet } \\
\text { width. } \\
\text { 9. Ratio: terminal leaflet width/terminal leaflet } \\
\text { length form axis of widest point to apex. } \\
\text { 10. Terminal leaflet petiolule length. } \\
\text { 11. Primary dorsal lateral leaflet width. } \\
\text { 12. Primary dorsal lateral leaflet length from } \\
\text { axis of widest point to apex. } \\
\text { 13. Ratio: primary dorsal lateral leaflet } \\
\text { length/primary dorsal lateral leaflet width. } \\
\text { 14. Ratio: primary dorsal lateral leaflet } \\
\text { width/primary dorsal leaflet length } \\
\text { from axis of widest point to apex. } \\
\text { 15. Primary dorsal lateral leaflet petiolule } \\
\text { length. }\end{array}$ & $\begin{array}{l}\text { 16. Pedicel length. } \\
\text { 17. Ratio: pedicel length/pedicel length from } \\
\text { base to articulation. } \\
\text { 18. Calyx length. } \\
\text { 19. Ratio: calyx length/calyx lobe length. } \\
\text { 20. Calyx lobe width at base. } \\
\text { 21. Sepal acumen length (see text). } \\
\text { 22. Calyx pubescence: glabrous (0), } \\
\text { pubescent (1). } \\
\text { 23. Corolla color (see text): violet blue (1), white } \\
\text { tinged with violet blue towards the tips (2), } \\
\text { white (3), gray-white (4), yellow-white (5), } \\
\text { deeper yellow-white (6), and yellow ( } 7) \text {. } \\
\text { 24. Corolla radius, measured from the center of } \\
\text { the corolla to the tip of the corolla lobes. } \\
\text { 25. Ratio: corolla radius/corolla radius from } \\
\text { center to base of corolla lobe. } \\
\text { 26. Corolla lobe width. } \\
\text { 27. Ratio: corolla lobe width/length from a line } \\
\text { drawn across widest point of corolla lobes. } \\
\text { 28. Anther length. } \\
\text { 29. Style length. } \\
\text { 30. Number of flowers per inflorescence, (see } \\
\text { Spooner and van den Berg 1992a, for } \\
\text { illustrations of characters } 24 \text {, } 25,26 \\
\text { and } 27 \text { ). }\end{array}$ \\
\hline
\end{tabular}


Each character was analyzed for its mean, range, standard deviation, and significance by one-way ANOVA in Minitab (Ryan et al., 1985). Dendrograms including all characters and a reduced subset of characters including only those characters statistically different between subspecies $(p<=0.05)$ were produced by NTSYS-pc ${ }^{R}$, version 1.70 (Rohlf, 1992). Averages for each character were standardized (STAND) and similarity matrices (in SIMINT), using average taxonomic distance (DIST), Manhattan distance (MANHAT), and product-moment correlation (CORR) were generated. Clustering was performed using the unweighted pair-group method (UPGMA) in SAHN. Cophenetic correlation coefficients (COPH, in MXCOMP) were used to measure distortion between the similarity matrices and the resultant two phenograms (Rohlf and Sokal, 1981; Sokal, 1986). Principal Components Analysis was performed with CORR similarity matrices and EIGEN.

\section{Nuclear DNA}

Pooled leaf samples of ten plants per accession of the NRSP-6 germplasm accessions were collected from 2-month-old plants for DNA extraction. DNA of the recent collections in Mexico was extracted from 10 pooled leaf samples collected in the field and preserved in silica gel (Chase and Hillis, 1991). Preparations of total DNA were made from about $5 \mathrm{~g}$ of fresh or $2 \mathrm{~g}$ of dried leaf tissue by the procedure of Doyle and Doyle (1987), substituting 6x CTAB for 2x CTAB (Smith et al., 1991). DNA was purified over CsCl/ ethidium bromide gradients. Restriction endonuclease digestions, agarose-gel electrophoresis, unidirectional Southern transfers to nylon membranes (Biotrans ${ }^{\mathrm{TM}}$ ), filter hybridization, and autoradiography followed methods in Palmer (1986).

Five $\mu \mathrm{g}$ of each DNA sample were digested with Dral and EcoRI restriction endonucleases according to manufacturer's instructions. Gel electrophoresis, unidirectional Southern transfers to nylon membranes (Zeta Probe ${ }^{\mathrm{TM}}$ ), and autoradiography followed methods in Giannattasio and Spooner (1994b). Hybridization and pre-hybridization used formamide protocols at $42^{\circ} \mathrm{C}$ (Havey, 1991).

Twenty three nuclear clones from potato, designated as $\mathrm{P}$ clones (Hosaka and Spooner, 1992) and tomato, designated as TG clones (Tanksley et al., 1992) were used as hybridization probes for RFLP analysis (P43, P122, P140, P161, P209, P215, P265, P279, P368, P374, P392, P403, P417, P434, P463, P543, P562, P573, P620; T36, T130, T134, T180). The clones were amplified by the Polymerase Chain Reaction and radiolabeled with ${ }^{32} p-d C T P$ by the method of Feinberg and Vogelstein (1984).

Only clearly visible bands were scored from only one enzyme per probe to avoid over scoring possible structural mutations (Giannattasio and Spooner, 1994b), except P463 where all accessions gave completely different information and there was evidently no duplication of information. Variable bands were converted to one (presence) and zero (absence) data. Similarity matrices were performed using Jaccard's $(\mathrm{J})$ and simple matching (SM) coefficients. Clustering was performed using the unweighted pair-group method (UPGMA) in SAHN. Cophenetic correlation coefficients (COPH, in MXCOMP) were used to measure distortion between the similarity matrices and the resultant two phenograms (Rohlf and Sokal, 1981; Sokal, 1986). Principal Components Analysis was performed with CORR similarity matrices and EIGEN. 
RESULTS

Morphology

Individual and averaged data for $S$. bulbocastanum are listed in Rodríguez (1994). One-way ANOVA demonstrated that only three characters examined differed significantly $(p<=0.05)$ between subspecies (Table 4): 5 . petiole length; 17 . ratio: pedicel length/pedicel length from base to articulation; and 22. calyx pubescence. Hawkes (1990) used only one of these characters, calyx pubescence, to distinguish subspecies. There was extensive variation in the ranges of character states among subspecies for all three characters.

The phenogram using all 19 morphological characters produced by DIST (not shown, but see Rodríguez, 1994) had the greatest cophenetic correlation coefficient (0.91), but did not separate the subspecies of $S$. bulbocastanum. There were no clusters with a geographic component that would support subspecies, regardless of prior identifications. The DIST phenogram using only the three morphological characters (also highest cophenetic correlation coefficient $=0.91$ ) showing statistical significance between subspecies (not shown, but see Rodríguez, 1994), and the PCA (not shown), likewise failed to separate subspecies.

Individual and averaged data for S. cardiophyllum are listed in Rodríguez (1994). The phenogram using all 26 morphological characters with DIST (not shown, but see Rodríguez, 1994) had a cophenetic correlation coefficient of 0.78 , but did not separate the subspecies of $S$. cardiophyllum. One-way ANOVA based on three subspecies demonstrated that five characters differed significantly $(p<=0.05)$ between subspecies: 11 . primary dorsal lateral leaflet width; 12. primary dorsal lateral leaflet length from axis of widest point to apex; 16. pedicel length; 23. corolla color; and 28. anther length. Hawkes (1990) used only one of these characters, anther length, to distinguish subspecies. The phenogram using these five characters with DIST (not shown, but see Rodríguez, 1994) had a cophenetic correlation coefficient of 0.82 and intermixed both accessions of subsp. lanceolatum with all but one accession of subsp. cardiophyllum and two of the 20 accessions of subsp. ehrenbergii. There were no clusters with a geographic component.

Because the above phenogram (and PCA) showed some support for $S$. cardiophyllum subsp. ehrenbergii (but did not distinguish subsp. cardiophyllum from subsp. lanceolatum), the ANOVA was run using only two groups: subsp. ehrenbergii, and subsp. cardiophyllum + subsp. lanceolatum. The ANOVA showed seven characters that differed significantly $(p<=0.05)$ between these two groups: 11 . primary dorsal lateral leaflet width; 12. primary dorsal lateral leaflet length from axis of widest point to apex; 16 . pedicel length; 17. ratio: pedicel length/pedicel length from base to articulation; 23 . corolla color; 28. anther length; and 29. style length. As in S. bulbocastanum, there was extensive variation in the ranges of character states among subspecies (Fig. 2).

The phenogram using only the seven morphological characters with DIST (also with the highest cophenetic correlation coefficient $=0.80$; Fig. 3), and the PCA (not shown) separated most accessions of $S$. cardiophyllum subsp. ehrenbergii from the other subspecies. 


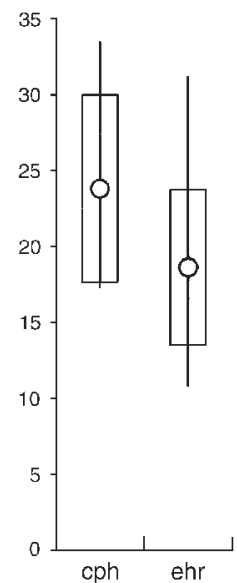

11. Primary dorsal lateral leaflet width

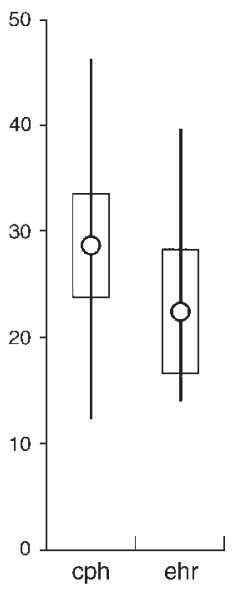

12. Primary dorsal lateral leaflet length from axis of widest point to apex
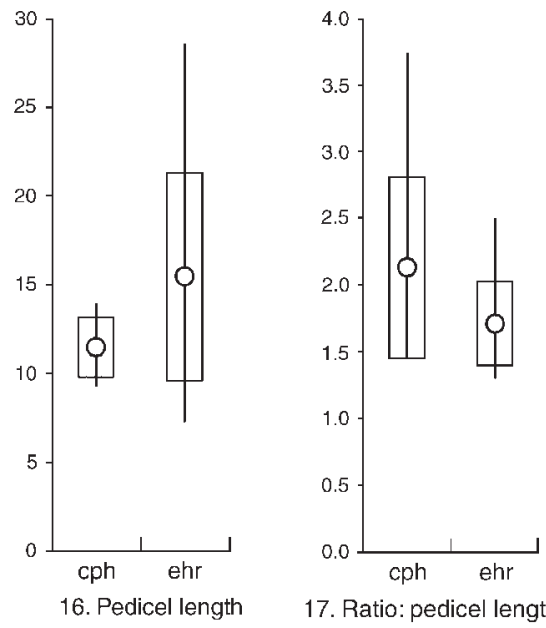

17. Ratio: pedicel length/pedice length from base to articulation
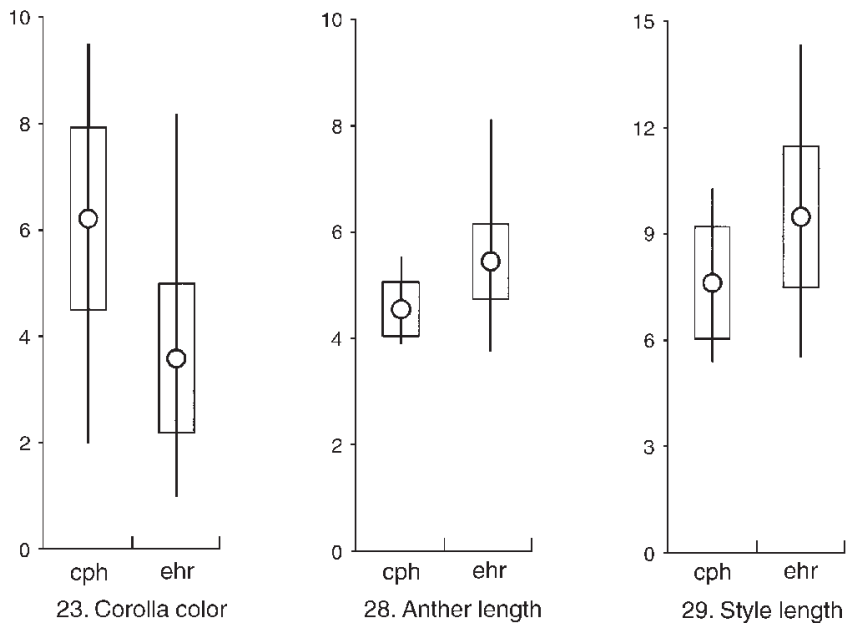

28. Anther length

29. Style length

Fig. 2. Means, ranges, and one standard deviation of the mean for the seven morphological characters showing significant differences between Solanum cardiophyllum subsp. cardiophyllum + subsp. lanceolatum (cph), and subsp. ebrenbergii (ehr) $(\mathrm{p}<=0.05)$. 


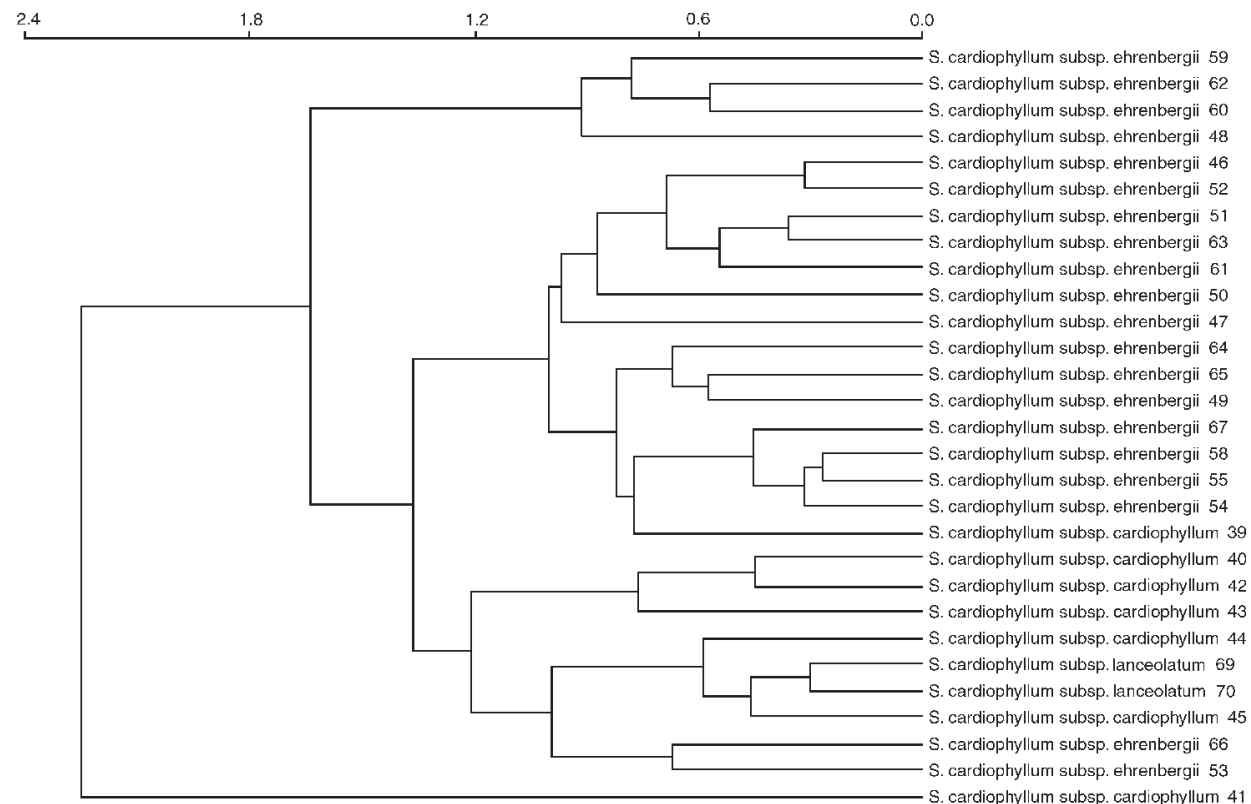

Fig. 3. UPGMA phenogram (DIST similarity option) based on seven of the 26 morphological characters that showed statistically significant differences among the subspecies of Solanum cardiophyllum $(\mathrm{p}<=0.05)$.

\section{Nuclear DNA}

The 23 clones produced 71 clearly scoreable bands (Rodríguez, 1994). The phenograms with $\mathrm{J}$ and SM coefficients had similar cophenetic correlation coefficients 0.95 and 0.94 , respectively, were extremely similar in topology, and are similar to the results of the PCA of the nDNA data. The J phenogram (Fig. 4) and the PCA define three welldefined clusters: S. bulbocastanum, S. cardiophyllum, and $S$. pinnatisectum. Within $S$. bulbocastanum, subsp. bulbocastanum and subsp. dolichophyllum do not cluster. The two accessions of subsp. partitum cluster, but within a part of the phenogram containing representatives of the other two subspecies. Within $S$. cardiophyllum, all accessions of subsp. cardiophyllum and one of the two accessions of subsp. lanceolatum cluster separately from all representatives of subsp. ehrenbergii and the other accession of subsp. lanceolatum. 
Rodríguez y Spooner: Subspecies the Solanum bulbocastanum and S. cardiophyllum

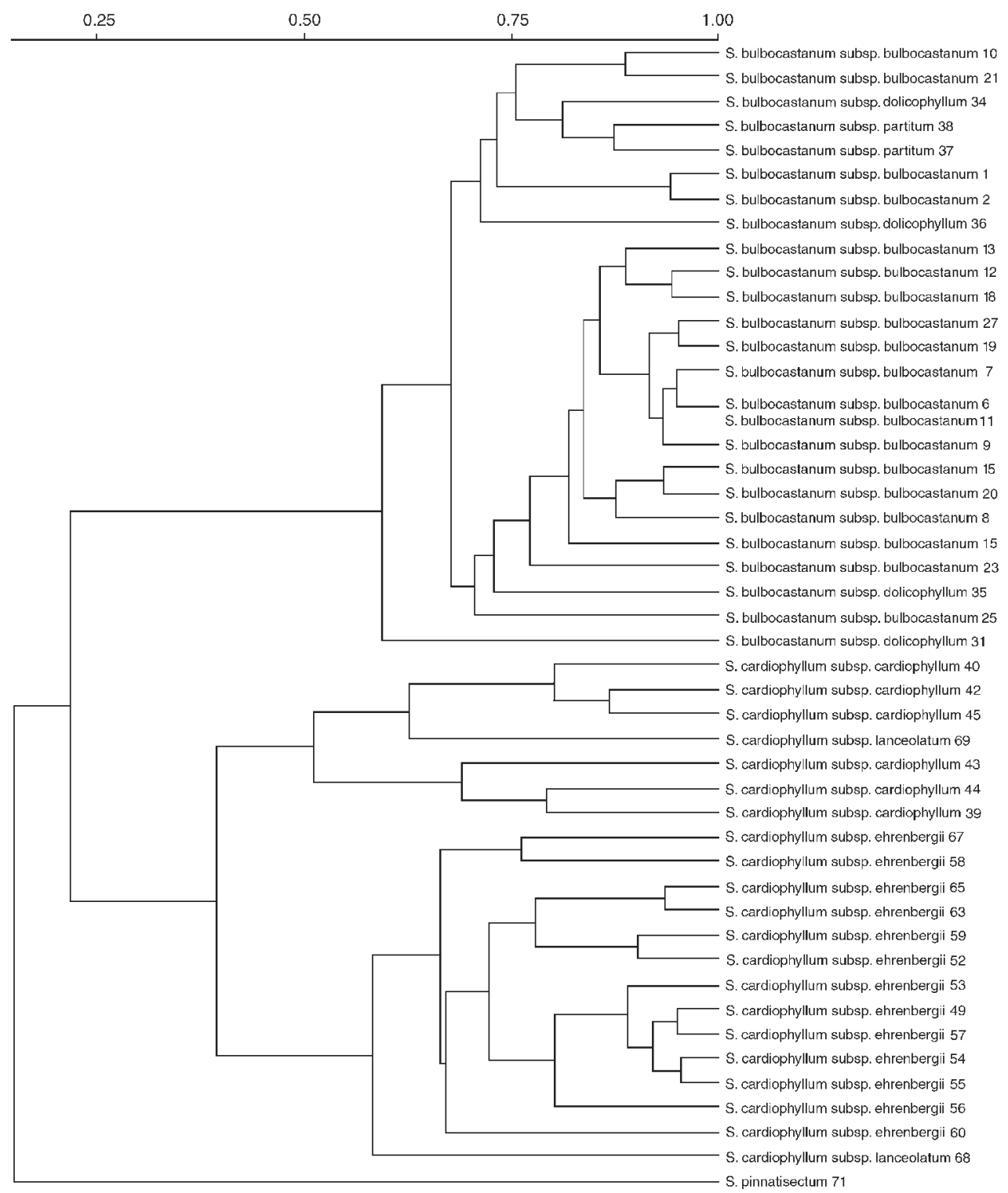

Fig. 4. UPGMA phenogram ( $\mathrm{J}$ similarity option) based on 71 nDNA bands of Solanum bulbocastanum, S. cardiophyllum and S. pinnatisectum. 


\section{DISCUSSION}

Subspecies circumscriptions

The morphological and molecular results, exclusive of $S$. cardiophyllum subsp. ehrenbergii, fail to support subspecies within $S$. bulbocastanum and $S$. cardiophyllum. Neither is there a geographical component to the morphological or molecular phenograms suggesting subspecies differentiation. Exclusive of subsp. ehrenbergii, the only suggestion of subspecies differences is seen in the results of the $S$. cardiophyllum morphological reduced data set (Fig. 3), where both examined accessions of subsp. lanceolatum cluster. However, these accessions are intermixed with both other subspecies, and the "defining" character state of narrow leaflets varies tremendously in the other subspecies.

Origin of Solanum cardiophyllum subsp. ehrenbergii

The morphological results (Figs. 2, 3, 4) show subsp. ehrenbergii to be similar to other two subspecies. The cpDNA results however show subsp. ehrenbergii to be on a very well-separated clade, containing other Mexican diploid species, separate from the other subspecies of $S$. cardiophyllum. These data suggest that subsp. ehrenbergii may have been formed by hybridization of $S$. cardiophyllum and a species in the Mexican diploid species clade (Spooner and Sytsma, 1992), or one of their relatives. Correll (1962) insightfully suggested that Solanum cardiophyllum subsp. ehrenbergii was a "connecting link" between $S$. cardiophyllum and the members of the Mexican diploid species clade. This hypothesis of hybrid origin, however, awaits more complete species sampling.

Implications for the number of taxa of sect. Petota

This study shows the value of parallel morphological and molecular data when investigating systematics of sect. Petota. Giannattasio and Spooner (1994a,b) showed general concordance of morphological and nDNA data, and suggested that $S$. megistacroloum Bitter and $S$. toralapanum Cárdenas should be reduced to subspecies rank. Van den Berg et al. (1998) and Miller and Spooner (1999) showed general concordance of morphological, RFLP and RAPD data for the Solanum brevicaule complex, and like this study suggested that there are too many wild potato taxa recognized. This study, on the other hand, shows discordance of morphological and molecular data suggesting that subsp. ehrenbergii may be a hybrid of $S$. cardiophyllum and a member of the Mexican diploid species clade. Spooner and Hijmans's (2001) compilation of 199 currently accepted species of wild potatoes surely will continue to be reduced.

\section{ACKNOWLEDGMENTS}

We thank Raul Castillo and Joseph T. Miller for technical assistance; Ofelia Vargas for help in collecting in Mexico; John Bamberg and staff at the United States Potato Genebank for growing accessions in field plots; Andrew Wynn Rouse for artwork; Kazuyoshi Hosaka and Stephen Tanksley for potato and tomato DNA probes; Michael J. 
Havey for comments on an earlier draft of the manuscript; and Jan Tivang for statistical advice. This work has been supported by a scholarship to Aarón Rodríguez from the University of Guadalajara (Exp. 367, No. 8328) and by the U.S.D.A., including germplasm collecting grants to David M. Spooner.

\section{REFERENCES}

Anonymous. 1986. RHS Colour chart. 2nd ed. Royal Horticultural Society. London.

Bamberg, J. B., M. W. Martin, J. J. Schartner and D. M. Spooner. 1996. Inventory of tuber-bearing Solanum species: catalog of germplasm. Potato Introduction Station. Sturgeon Bay, WI. 110 pp.

Bamberg, J. B. and D. M. Spooner. 1994. The United States Potato Introduction Station Herbarium. Taxon 43: 489-496.

Bitter, G. 1912. Solana nova vel minus cognita VI. Feddes Repert. Spec. Nov. Regni Veg. 11: 431473.

Bukasov, S. M. 1978. Systematics of potato species (in Russian). English translation of article first appearing in Trudy Prikl. Bot., Genet. Selekcii 62:3-35. In: Kothetar, V. S. (ed.), Dhote, A. K. (translator). Systematics, breeding and seed production of potatoes. Amerind Publishing Co. New Delhi. 42 pp.

Chase, M. W. and H. H. Hillis. 1991. Silica gel: an ideal material for field preservation of leaf samples for DNA studies. Taxon 40: 215-220.

Correll, D. S. 1962. The potato and its wild relatives. Contr. Texas Res. Found., Bot. Stud. 4: 1-606.

Debener, T., F. Salamini and C. Gebhardt. 1990. Phylogeny of wild and cultivated Solanum species based on nuclear restriction fragment length polymorphisms (RFLPs). Theor. Appl. Genet. 79: $360-368$.

Doyle, J. J. and J. L. Doyle. 1987. A rapid DNA isolation procedure for small quantities of fresh leaf tissue. Phytochem. Bull. Bot. Soc. Amer. 19: 11-15.

Feinberg, A. P. and B. Vogelstein. 1984. A technique for radiolabeling DNA restriction endonuclease fragments to high specific activity. Analytical Biochem. 137: 266-267.

Flores-Crespo, R. 1966. Estudio preliminar del género Solanum, sección Tuberarium, subsección Hyperbasarthrum en México. Bachelor of Science thesis, Facultad de Ciencias, Universidad Nacional Autónoma de México. México, D.F. 100 pp.

Gell, P. G. H., J. G. Hawkes and S. T. C. Wright. 1960. The application of immunological methods to the taxonomy of species within the genus Solanum. Proc. Roy. Soc. London, Ser. B, Biol. Sci. 151: 364-383.

Giannattasio, R. B. and D. M. Spooner. 1994a. A reexamination of species boundaries between Solanum megistacrolobum and S. toralapanum (Solanum sect. Petota, series Megistacroloba): morphological data. Syst. Bot. 19: 89-105.

Giannattasio, R. B. and D. M. Spooner. 1994b. A reexamination of species circumscriptions between Solanum megistacrolobum and S. toralapanum (Solanum sect. Petota, series Megistacroloba): molecular data. Syst. Bot. 19: 106-115.

Graham, M. K. and L. A. Dione. 1961. Crossability relationships of certain diploid Mexican Solanum species. Can. J. Genet. Cytol. 3: 121-127.

Graham, M. K., J. S. Niederhauser and L. Servin. 1959. Studies on fertility and late blight resistance in Solanum bulbocastanum Dun. in Mexico. Canad. J. Bot. 37: 41-49.

Hanneman, R. E. Jr. 1994. Assignment of endosperm balance numbers to the tuber-bearing solanums and their close non-tuber bearing relatives. Euphytica 74: 19-25.

Havey, M. L. 1991. Phylogenetic relationships among cultivated Allium species from restriction enzyme analysis of the chloroplast genome. Theor. Appl. Genet. 81: 752-757. 
Hawkes, J. G. 1958. Potatoes: taxonomy, cytology and crossability. In: Kappert, H. and W. Rudorf (eds.). Handbuch der Pflanzenzüchtung. 2nd ed. vol. 3. Paul Parey, Berlin. pp 10-43.

Hawkes, J. G. 1990. The potato: evolution, biodiversity and genetic resources. Belhaven Press. London. $259 \mathrm{pp}$.

Hosaka, K. and D. M. Spooner. 1992. RFLP analysis of the wild potato species, Solanum acaule Bitter (Solanum sect. Petota). Theor. Appl. Genet. 84: 851-858.

Luna, M., T. L. Wendt and M. E. García. 1988. Estudio biosistemático de papas arvenses (Solanum secc. Petota) del altiplano potosino-zacatecano. Agrociencia 71: 103-120.

Magoon, M. L., D. C. Cooper and R. W. Hougas. 1958. Cytogenetic studies of some diploid solanums section Tuberarium. Amer. J. Bot. 45: 207-221.

Miller, J. and D. M. Spooner. 1999. Collapse of species boundaries in the Solanum brevicaule complex: molecular data. PI. Syst. Evol. 214: 103-130.

Palmer, J. D. 1986. Isolation and structural analysis of chloroplast DNA. Meth. Enzymol. 118: 167-186.

Rodríguez, A. 1991. Las papas silvestres (género Solanum, sección Petota, subsección Potatoe) en Jalisco. Bachelor of Science thesis, Universidad de Guadalajara. Guadalajara, Jalisco, México. 125 pp.

Rodríguez, A. 1994. Molecular and morphological systematics of Solanum bulbocastanum and S. cardiophyllum, and evidence for the hybrid origin of $S$. ehrenbergii (Solanum sect. Petota). M. S. Thesis, University of Wisconsin. Madison, WI. 112 pp.

Rodríguez, A. and D. M. Spooner. 1997. Chloroplast DNA analysis of Solanum bulbocastanum and S. cardiophyllum, and evidence for the distinctiveness of $S$. cardiophyllum subsp. ehrenbergii (sect. Petota). Syst. Bot. 22: 31-43.

Rodríguez, A., O. Vargas, E. Villegas and D. M. Spooner. 1995. Wild potato (Solanum sect. Petota) germplasm collecting expedition to Mexico in 1993, with special reference to Solanum bulbocastanum Dunal and S. cardiophyllum Lindley. Potato Res. 38: 47-52.

Rohlf, F. J. 1992. NTSYS-pc, numerical taxonomy and multivariate analysis system. Exeter Publishing Ltd. New York. 31 pp.

Rohlf, F. J. and R. R. Sokal. 1981. Comparing numerical taxonomic studies. Syst. Zool. 30: 459-490.

Ryan, B. F., B. L. Joiner and T. A. Ryan. 1985. Minitab handbook. 2nd ed. PWS-Kent. Boston, MA.

Rydberg, P. A. 1924. The section Tuberarium of the genus Solanum in Mexico and Central America. Bull. Torrey Bot. Club 51: 145-153.

Smith, J. F., K. J. Sytsma, R. L. Shoemaker and R. L. Smith. 1991 (1992). A qualitative comparison of total cellular DNA extraction protocols. Phytochem. Bull. Bot. Soc. Amer. 23: 2-9.

Sokal, R. R. 1986. Phenetic taxonomy: theory and methods. Ann. Rev. Ecol. Syst. 17: 423-442.

Spooner, D. M. and J. B. Bamberg. 1991. The Inter-Regional Potato Introduction Project (IR-1), U.S. center for potato germplasm. Diversity 7(3): 32-35.

Spooner, D. M., J. B. Bamberg, J. P. Hjerting and J. Gómez. 1991. Mexico, 1988 potato germplasm collecting expedition and utility of the Mexican potato species. Amer. Potato J. 68: 29-43.

Spooner, D. M. and R. Hijmans. 2001. Potato systematics and germplasm collecting, 1989-2000. Amer. J. Potato Res. 78: 237-268.

Spooner, D. M. and K. J. Sytsma. 1992. Reexamination of series relationships of Mexican and Central American wild potatoes (Solanum sect. Petota): evidence from chloroplast DNA restriction site variation. Syst. Bot. 17: 432-448.

Spooner, D. M. and R. G. van den Berg. 1992a. Species limits and hypotheses of hybridization of Solanum berthaultii Hawkes and S. tarijense Hawkes: morphological data. Taxon 41: 685-700.

Spooner, D. M. and R. G. van den Berg. 1992b. An analysis of recent taxonomic concepts in wild potatoes (Solanum sect. Petota). Genet. Res. Crop Evol. 39: 23-27.

Spooner, D. M., R. van den Berg, A. Rodríguez, J. Bamberg, R. J. Hijmans and S. I. Lara-Cabrera. In press. Wild potatoes (Solanum section Petota) of North and Central America. Systematic Botany Monographs. 
Swaminathan, M. S. 1955. Overcoming cross-incompatibility among some Mexican diploid species of Solanum. Nature 176: 887-888.

Tanksley, S. D., M. W. Ganal, J. P. Prince, M. C. De Vicente, M. W. Bonierabale, P. Broun, T. M. Fulton, J. J. Giovannoni, S. Grandillo, G. B. Martin, R. Messeguer, J. C. Miller, L. Miller, A. H. Paterson, O. Pineda, M. S. Røder, R. A. Wing, W. Wu and N. D. Young. 1992. High density molecular linkage maps of the tomato and potato genomes. Genetics 132: 1141-1160.

Tucker, A. O., M. H. Maciarello and S. S. Tucker. 1991. A survey of color charts for biological descriptions. Taxon 40: 201-214.

Van den Berg, R., J. Miller, M. L. Ugarte, J. Kardolus, J. Villand, J. Nienhuis and D. M. Spooner. 1998. Collapse of morphological species in the wild potato Solanum brevicaule complex (sect. Petota). Amer. J. Bot. 85: 92-109. 